\title{
Urban Resilience Assessment of Trabzon
}

\section{Doğan DURSUN $^{1 *}$, Defne DURSUN ${ }^{1}$, Ahmet Burak KAYA ${ }^{1}$}

\begin{abstract}
Negative environmental developments in the modern urban world such as pollution, disasters, scarcity of sources and climate change necessitates regulations and introduce the urgent need for new urban planning approaches. The concept of "resilience" becomes a contemporary issue in this process and it takes the discussions on sustainability, management of risks and governance a step further. Resilience is mainly a capacity of system to cope with external unexpected risks. In the urban area, the concept means adaptation and coping capacity of urban systems against shocks, risks, disasters and emergencies which may arise. The main aim of this study is to evaluate existing urbanization practices of Trabzon in terms of the concept of resilience. In the first stage, the resilience concept and its new initiatives in the planning area are discussed. Then, framework for the analysis of Trabzon is presented. Later, Criteria and measurement methods were analyzed within the framework of twelve different studies. In the scope of these studies, social, economic, physical-ecological, administrative and political resilience perspectives were defined. In this direction, 49 indicators were prepared in accordance with the national database and new method was searched for the evaluation of the Turkish case within the resilience perspective. The findings showed that Trabzon is a non-resilient city and creating risks in terms of the topics studied. A planning approach should be developed from the perspective of resilience for the city. Otherwise, it is obvious that the city will be faced with big risks in the future in terms of livability.
\end{abstract}

Keywords: Resilient city, adaptation, planning, Trabzon

${ }^{1}$ Doğan DURSUN (Orcid ID: 0000-0003-3791-0027), Defne DURSUN (Orcid ID: 0000-0003-4560-744X), Ahmet Burak KAYA (Orcid ID: 0000-0002-1530-9671), Atatürk Üniversitesi, Mimarlık ve Tasarım Fakültesi, Şehir ve Bölge Planlama Bölümü, Erzurum, Türkiye

*Sorumlu Yazar/Corresponding Author: Doğan DURSUN, e-mail: dogan08@gmail.com

Makale 30Ağustos-1 Eylül 2019 tarihlerinde Chiba Üniversitesi'nde (Japonya) düzenlenen "International Conference on Spatial Planning and Sustainable Development" sözlü olarak sunulmuştur.

Geliș tarihi / Received: 06-12-2019

Kabul tarihi / Accepted:25-01-2020 


\section{INTRODUCTION}

The importance of the concept of resilience is increasing as it refers to sustainable urban development and ways how to deal with the factors threatening urban life. Actually, resilience concept, which is predicated on increasing the capacities to struggle and survive at sudden shocks and stress conditions, also involves diminishing the vulnerabilities. While this concept is generally used in ecology field, nowadays it is started to be used within economic and social fields, too.

There are threats and risks for cities to preserve and develop their existing economic, social end ecological positions. Cities should be dynamic and creative as they may face a new development in this global competitive economy, any time. They should also develop environmental decisions, which provide the development of spatial improvements sensitive to ecological changes such as global warming. Thus, cities should develop strategies to increase their resilience capacities in such an environment where the attitude of social structures; that is both innovator and open to diversities; determines other resilience capacities of them.

The aim of this study is to discuss the resilience concept and make some urban analysis for the city of Trabzon through this perspective. Thus, first of all, the concept of resilience was explained and its scope was specified. Then, the indicators for analysis regarding economic, social, physical, ecological, administrative and political resilience were determined. At the third stage, all these variables were tested through Trabzon case and it is compared and evaluated with OECD countries over 100 points. The last section of the paper includes the determination of the ecologic, spatial, economic, social, administrative and politic resilience levels of Trabzon within the scope of these variables. Thus, the main problem areas of Trabzon to increase the resilience of it were identified.

\section{The Concept of Resilience and Planning}

The main feature of a resilient system is its capacity to deal with change and degeneration (Walker and Salt, 2006; Eraydın, 2010). Providing the preservation and continuity of a system as it is with its basic functions and structures is important with regards to resilience. In fact, resilience is the defense capacity that can be described as being prepared to future shocks (Adger, 2000; Eraydin, 2010). It is a concept contrary to fragility; because if a system loses its economic, ecologic and social resilience, it becomes vulnerable to changes, risks and shocks. Resilience as foreseeing capacity comprises the process of planning and minimizing the effects of crisis through system changes by predicting them beforehand (Aguirre, 2006). Thus, this concept does not only involve answering and adaptation but also involves preventive arrangements (Baud and Hordijk, 2009). In this context, resilience concept becomes an approach that can be involved in urban planning, design and participation processes. Thus, resilience concept, its approach and policies change direction from controlling the changes in order to provide the system to maintain its condition, to multiple meanings such as struggling, adaptation, managing the change, creating new opportunities and innovation. (Eraydın, 2010). Resilience perspective provides an important framework to provide the sustainability of development, for the conditions that it is possible to encounter some negative surprises and when the future cannot be estimated. All these approaches come forward as the facilitator elements for the use of resilience concept in urban planning field.

Both urban planning and urban resilience approaches accept cities as complicated social and ecologic systems that are also adaptive. Determination of the fragility and adaptation capacities of cities comprises the first step for the resilience based urban planning works. Thus, putting forward the identicators and techniques of detecting the existing situation; determining the principles and opportunities has been the key actions for resilience planning. 
The guide made for understanding the resilience of urban systems (Urban Resilience Research Prospectus, 2007) states that understanding the quality of life, governance networks, learning capability of societies, social dynamics, flows between urban activities, economic activities, built structure and the relations with it has an important role in this process. Thus, resilience concept is no more limited with ecology; from which it shaped, but involves social and economic resilience concepts, too. The works emphasizing the versatile structure of resilience (Berkes and Folke, 1998; Adger, 2000; Folke and Carpenter, 2000; Abel et.al, 2006; Eraydın, 2010) also states that all three fields are interconnected with each other. That is, to increase the resilience capacity of an urban system and a region, an analysis made with ecologic, economic and social indicators and a plan developed by means of the findings of this analysis is needed.

The fluctuations in the world caused by intensive globalization reveal that any time there can be a new development, a threat, a disaster or a shock. Resilient city and resilient planning approach provides a framework for the existing systems not to collapse but to sustain with more power.

\section{Economic Resilience}

Economic resilience is one of the concepts become prominent as the production and consumption chains get more complicated owing to the increasing global network relations. Cities are the nodes for the flows of goods, capital, ideologies, technology and people. The world economy had been reorganized according to these flows and the cities that control them and still open to perpetual change; which makes it harder to sustain the economic success. Thus, cities and regions should develop their capacities in order to adapt the changing conditions, to be sensitive to the changing flows, rivalry conditions, crisis and alterations of global economy.

There are three different types of results of these economic crisis and shocks for cities and regions (Eraydın et.al., 2011). Some of the cities; which called to be economically resilient cities; can go back to their previous development levels and even sometimes pass it being more successful. Some other cities are not affected by crisis or any shocks and continue to sustain their existing development levels. These cities are called to be resilient cities. However, third type of cities/regions, the ones that are not resilient; cannot compete with those crises and cannot catch up their previous development levels (Hill et.al., 2008).

To analyze the economic resilience of cities/regions, it is enough to look at the economic performances of them before and after the crisis. Indicators such as increase in capital and population, employment and quality of life are also used to measure the economic resilience. However, to talk about the resilience of a city, we should talk about its economic success.

\section{Social Resilience}

The social structure of a city or a region is the determinant of its adaptation capacity against new situations. The character of the people is the distinctive property of them providing them to survive after crisis, shocks or threats. Maguire and Hagan (2007) define social resilience concept as the capability of societies to overcome negative situations and transform them to positive. According to them social resilience concept has three components; i.e. resistance, recovery/overcoming, and creativity. The societies with these properties are accepted to have very high degree of resilience. 'Resistance' is about surviving of the societies from the disasters, acute shocks and their unfavorable results; while 'recovery' indicates the capability of the society to heal and turn back to the previous conditions. 'Creativity' states the capacity of the society to learn from unfavorable situations, to adapt these conditions and grow to a better position from its previous one. These arguments put forward that these three components of social 
resilience also determine economic resilience, as being resilient due to the structure of the society reveals betterment in the economy of the city/region.

The question is how to evaluate the social resilience of a city or a region; as the social structure has so many variables that cannot be measured quantitatively. It is decided upon that, the demographic properties and the changes in demographic structure of a settlement are the ones to start with. Thus, education level, age and gender structure, age dependency ratios, flow to and from the city, and some variables related to quality of life are the foremost indicators of social resilience. High levels of education, high ratios of young population, increased labor force participation of women, and higher levels of education of the ones migrated to the city indicate higher levels of social resilience for the case city/region. However, as the start to loose regarding these variables, it became more vulnerable to any threats and shocks.

\section{Ecological-Physical Resilience}

Ecological resilience concept is related with ecosystems and needed to provide their continuity. Ecosystem itself is used as a potential in future scenarios. However, its damages negatively affect existing living conditions. Both natural developments such as disasters and other developments reasoned by human beings damages the ecosystem and thus the ecological resilience. The adaptation capacity of a city or a region to changing conditions is also affected by the damages made to ecosystems. The natural values that are lost and the urban ecosystems that were incorrectly built downscale the resilience of the related city/region against disasters and other changes increasing their fragility.

First two of the indicators used to determine the ecological resilience is urban sprawl and unplanned developments (Eraydin et.al., 2011). These two developments which decreases both ecological and spatial resilience, also minimizes the adaptation capacities. Except from consuming the natural resources, wrong land use decisions also trigger some negativities. Unplanned development process through the formation of urban macroform increases the problems and diminishes the resilience. Moreover, adaptation capacity of cities also diminishes as the urban sprawl process ends up with the consumption of agricultural areas. Travels increase in both number and time, traffic problems arise and energy waste rises. Inadequacy of public transportation systems encourages the usage of personal vehicles, and then the increasing traffic and pollution caused negatively effects ecological resilience.

The effects of urban development models to ecosystems are highly discussed in the literature. Sprawled and compact urban models have different affects to the environment. However, compact urban models are preferred from the ecological resilience perspective.

\section{Administrative-Politic Resilience}

Within the globalized capitalist system, management organization is one of the prominent concepts. In this new global system where cities are the focal points, there is an importance of the capital, commodity and production of technology, as well as the increasing importance of administrative organizations in urban area.

Resilience management has started to be discussed in the literature as an important branch of the resilience concept in recent years. Administrative resilience aims to provide administrative flexibility as a part of daily work with the intention of helping cities in a time of any possible crisis. Administrative Resilience; clarify the inter-agency tasks by defining how different activities will be carried on. Also, it helps the creation of institutional rules.

There are some indicators used for determining the administrative-political resilience. One of them is about the existence of the emergency action plans of administrative organizations. Absence of the 
emergency action plan is accepted as a factor decreasing the adaptive capacity of both ecological and physical resilience (McManus et al., 2007). Another indicator is administrative instability (Sharifi and Yamagata, 2016). The existence of administrative stability increases the speed of intervention by strengthening the link between various elements of the system.

\section{MATERIALS AND METHOD}

This research was carried out for Trabzon with the aim of analyzing resiliency by using the international criteria and calculate the resistance level of the city quantitatively. The 12 different studies were analyzed and 49 indicators were prepared in accordance with the national database within the framework of social, economic, physical, administrative-political and ecological resilience (Table 1). In this context, new evaluation method and scoring system are developed with the qualitative and quantitative indicators and the level of resilience for Trabzon is calculated. Quantitative indicators were compared with OECD countries and 2.04 points was calculated for the indicators having values higher than OECD average. 2.04 as the value of indicators is calculated by dividing 100 points to 49 indicators. If the value is less than OECD average, it was calculated as 0 points. In terms of qualitative indicators, if the answer is "Yes", the indicator gets 2.04 points. If it is "No", indicator get 0 points. Qualitative indicators were not used for physical and ecological resilience evaluation.

Table 1. List of studies used for the determination of resilience indicators

\begin{tabular}{|c|c|c|}
\hline Year & Title & References \\
\hline 2013 & $\begin{array}{l}\text { Determination of Vulnerability of Cities to Climate Change: The } \\
\text { Case of Ankara }\end{array}$ & Çobanyılmaz, Duman \\
\hline 2014 & City resilience index: City resilience framework. & TRF \\
\hline 2016 & $\begin{array}{l}\text { Urban Resilience Assessment: Multiple } \\
\text { Dimensions, Criteria, and Indicators }\end{array}$ & Sharifi, Yamagata \\
\hline 2009 & $\begin{array}{c}\text { Disaster Response: Research Findings and Their Implications for } \\
\text { Resilience Measures }\end{array}$ & Tierney \\
\hline 2008 & $\begin{array}{c}\text { Institute of Urban and Regional } \\
\text { Development UC Berkeley }\end{array}$ & Hill, Wial, \& Wolman \\
\hline 2008 & Towards the Resilient Region? & $\begin{array}{c}\text { Stuart Dawley, Andy Pike, } \\
\text { \& John Tomaney }\end{array}$ \\
\hline 2006 & $\begin{array}{c}\text { Performance-Based Planning } \\
\text { Perspectives from the United States, Australia, and New Zealand }\end{array}$ & $\begin{array}{l}\text { Douglas C. Baker, Neil G. Sipe, and } \\
\text { Brendan J. Gleeson }\end{array}$ \\
\hline 2010 & $\begin{array}{c}\text { Understanding social resilience to climate variability in primary } \\
\text { enterprises and industries }\end{array}$ & Marshall \\
\hline 2019 & $\begin{array}{l}\text { Analysis of the Global Resilience Assessment Frameworks for the } \\
\text { Urban Realm }\end{array}$ & Diaz J. \\
\hline 2005 & $\begin{array}{l}\text { An Exploratory Framework for the Empirical Measurement of } \\
\text { Resilience }\end{array}$ & $\begin{array}{l}\text { G. S. Cumming, G. Barnes, S. Perz, M. } \\
\text { Schmink, K. E. Sieving, J. } \\
\text { Southworth,M. Binford, R. D. Holt, C. } \\
\text { Stickler, and T. Van Holt }\end{array}$ \\
\hline 2008 & $\begin{array}{c}\text { Community and Regional Resilience: Perspectives from Hazards, } \\
\text { Disasters and Emergency Management }\end{array}$ & $\begin{array}{c}\text { Susan L. Cutter, Lindsey Barnes, } \\
\text { Melissa Berry, Christopher Burton, } \\
\text { Elijah Evans, Eric Tate, and Jennifer } \\
\text { Webb }\end{array}$ \\
\hline 2008 & Community Resilience: A Social Justice Perspective & Morrow B.H. \\
\hline
\end{tabular}

\section{RESULTS AND DISCUSSION}

In order to see the economic situation of Trabzon and its resiliency, three categories of indicators were defined related with general structure; economic dynamism; and socio-economic structure. Added value, unemployment and employment ratio, average age of working population, saving deposits, employment in agricultural sector, bank number and change in export figures are the criteria determined 
for the evaluation of general structure of economy. As it can be seen in Table 2, general economic structure Trabzon has shown low scores below the average of OECD. However, the city has increased saving deposits, number of bank and export volume in the last ten years. They can be evaluated positive developments in terms of economic resilience. In the second category, economic dynamism of the city is measured with the two indicators such as the existence of cooperative association and decreasing tendency of unemployment rate. They showed positive changes in terms of these indicators. When the socio-economic structure is analyzed in the last category of general economic situation, migration, active population, GDP, education and gender of working population are assessed. Only the active population number has a value above the average of OECD. The other indicators have displayed that educated people are going from the Trabzon to the other cities. Socio-economic structure and indicator based analyses demonstrated that Trabzon is a non-resilient city. But the city has a big potential to overcome existing economic problems. High number of young active population and increasing trend in general economic indicators in the last ten years are the positive developments for the resiliency of the city in the future.

Table 2. Evaluation of Economic Resilience in Trabzon

\begin{tabular}{|c|c|c|c|c|}
\hline \multicolumn{5}{|c|}{ Economic Resilience } \\
\hline Evaluation & Criteria & Trabzon & OECD & Number \\
\hline \multirow{13}{*}{$\begin{array}{l}\text { General } \\
\text { Structure }\end{array}$} & \multirow{2}{*}{${ }^{1}$ Added Value Per Capita \$ } & \multirow{2}{*}{3388} & \multirow{2}{*}{17542} & Above Average \\
\hline & & & & Below Average \\
\hline & \multirow{2}{*}{ Unemployment Ratio \% } & \multirow{2}{*}{7.4} & \multirow{2}{*}{5.7} & Above Average \\
\hline & & & & Below Average \\
\hline & \multirow{2}{*}{ Employment Ratio \% } & \multirow{2}{*}{46.8} & \multirow{2}{*}{72.1} & Above Average \\
\hline & & & & Below Average \\
\hline & \multirow{2}{*}{${ }^{2}$ Average Age of Working Population } & \multirow{2}{*}{38.8} & \multirow{2}{*}{45.4} & Above Average \\
\hline & & & & Below Average \\
\hline & \multirow{2}{*}{$\begin{array}{l}\text { Is the Ratio of Employment in Agricultural Sector to } \\
\text { Whole Employment less than the ratio of OECD \% }\end{array}$} & \multirow{2}{*}{36.65} & \multirow{2}{*}{29.3} & Above Average \\
\hline & & & & Below Average \\
\hline & $\begin{array}{l}\text { Is there an upward trend in the Saving Deposit } \\
\text { accounts in the last } 10 \text { years? }\end{array}$ & +44.7 & Yes & \\
\hline & $\begin{array}{l}\text { Is there a tendency of increase in the numbers of } \\
\text { bank in the last ten years? }\end{array}$ & $+\% 40$ & Yes & \\
\hline & $\begin{array}{l}{ }^{3} \text { Has the rate of change in export figures tended to } \\
\text { decline in the last } 10 \text { years? }\end{array}$ & $+\% 187$ & & No \\
\hline \multirow[b]{2}{*}{$\begin{array}{l}\text { Economic } \\
\text { Dynamism }\end{array}$} & Is there a national cooperative association? & & Yes & \\
\hline & $\begin{array}{c}{ }^{4} \text { Is there a tendency of decrease on unemployment } \\
\text { rate in the last } 10 \text { years? }\end{array}$ & $-\% 2.3$ & Yes & \\
\hline \multirow{10}{*}{$\begin{array}{l}\text { Socio- } \\
\text { Economic } \\
\text { Structure }\end{array}$} & \multirow{2}{*}{ Ratio of high school graduated working population $\%$} & \multirow{2}{*}{18.4} & \multirow{2}{*}{75.6} & Above Average \\
\hline & & & & Below Average \\
\hline & \multirow{2}{*}{$\begin{array}{c}\text { Is the ratio of high school graduates of incoming } \\
\text { immigrants higher than the high school graduates rate } \\
\text { of outgoing migration? }\end{array}$} & \multirow{2}{*}{28.9} & \multirow{2}{*}{38.4} & Above Average \\
\hline & & & & Below Average \\
\hline & \multirow{2}{*}{ Active Population Ratio (15-64 age) } & \multirow{2}{*}{79.2} & \multirow{2}{*}{77.9} & Above Average \\
\hline & & & & Below Average \\
\hline & \multirow{2}{*}{ GDP Per Capita (\$) } & \multirow{2}{*}{8.439} & \multirow{2}{*}{38.164} & Above Average \\
\hline & & & & Below Average \\
\hline & \multirow{2}{*}{ Female Gender Ratio of Working Population \% } & \multirow{2}{*}{44.3} & 477 & Above Average \\
\hline & & & 47.1 & Below Average \\
\hline $\begin{array}{l}{ }^{3} \text { Change of Exp } \\
{ }^{4} \text { Change in the }\end{array}$ & $\begin{array}{l}\text { apita OECD data: The added value of } 20 \text { OECD members wa } \\
\text { rking population: It is calculated by proportioning the values } \\
\text { system with the age group weight } \\
\text { figures in Trabzon: The export values of } 2007 \text { were calculate } \\
\text { mployment rate of Trabzon: The unemployment rate values c }\end{array}$ & $\begin{array}{l}\text { llected ar } \\
\text { aploymen } \\
\text { proporti } \\
07 \text { were }\end{array}$ & $\begin{array}{l}\text { an avera } \\
\text { arated by }\end{array}$ & $\begin{array}{l}\text { groups in the Turkish } \\
\text { ort data } \\
\text { ortions with the } 2017\end{array}$ \\
\hline
\end{tabular}


Social resilience is also examined for Trabzon in the context of this study. In this direction, social resilience indicators are defined under five categories as general structure, welfare state parameters, safety, health conditions and social capital (Table 3). In order to display general social structure, urbanization ratio, average household size, dependency ratio, child/mother ratio, net migration, number of elderly people, population growth, literacy rate and number of higher educated people are used as indicators. They showed that general social structure of Trabzon has non-resilient characteristics. In the future, Trabzon will need higher educated people to continue its economic and social level but indicators show the opposite. Car ownership is the only indicator showing welfare state for Trabzon due to the lack of data and demonstrated that it is below the OECD average. Safety issue is important for social resilience and Trabzon is solving this problem by increasing the number of police. This shows the unsafe conditions and low resilience of the city. Health conditions is the third category of indicators measured with the number of medical doctors, beds, life expectancy and suicide rate. They showed the score as not good as OECD examples and low resiliency for Trabzon. Social capital is the last category measured with the existence of only non-governmental organization due to the absence of data. There is no international non-governmental organization in Trabzon.

Ecological resilience is the other important category for the evaluation of Trabzon and examined under three categories in this study. Settlement pattern is tested with the indicators such as suitable areas, existence of slum areas, flood disasters, existence of sea fill areas and settlements on it. Trabzon has all those categories and ecologically non-resilient city. Sea fill area is increasing in each year. Open and green areas is the other parameters tested for Trabzon. They are not well organized spaces in the city and their areas are not consistent with the standards. Physical infrastructure seems good for nowadays.

Table 3. Evaluation of Social Resilience in Trabzon

\begin{tabular}{|c|c|c|c|c|}
\hline \multicolumn{5}{|c|}{ Social Resilience } \\
\hline Evaluation & Criteria & Trabzon & OECD & Number \\
\hline \multirow{19}{*}{$\begin{array}{l}\text { General } \\
\text { Structure }\end{array}$} & \multirow{2}{*}{${ }^{1}$ Urbanization Ratio (\%) } & \multirow{2}{*}{56} & \multirow{2}{*}{70} & Above Average \\
\hline & & & & Below Average \\
\hline & \multirow{2}{*}{${ }^{2}$ Average Household Size } & \multirow{2}{*}{4.25} & \multirow{2}{*}{2.6} & Above Average \\
\hline & & & & Below Average \\
\hline & \multirow{2}{*}{ Dependency Ratio (\%) } & \multirow{2}{*}{28.7} & \multirow{2}{*}{27.9} & Above Average \\
\hline & & & & Below Average \\
\hline & \multirow{2}{*}{${ }^{3}$ Child/Mother Ratio } & \multirow{2}{*}{1.9} & \multirow{2}{*}{1.7} & Above Average \\
\hline & & & & Below Average \\
\hline & \multirow{2}{*}{ Net Migration Ratio (\%) } & \multirow{2}{*}{$0.7+$} & \multirow{2}{*}{+2.5} & Above Average \\
\hline & & & & Below Average \\
\hline & \multirow{2}{*}{$\begin{array}{c}\text { Ratio of population aged over } 65 \text { in total } \\
\text { population }(\%)\end{array}$} & \multirow{2}{*}{8.42} & \multirow{2}{*}{15.2} & Above Average \\
\hline & & & & Below Average \\
\hline & Is the rate of population growth increasing (\%)? & $0.87+$ & Yes & \\
\hline & \multirow{2}{*}{$\begin{array}{c}\text { Ratio of population between } 0-15 \text { years in total } \\
\text { population }(\%)\end{array}$} & \multirow{2}{*}{18.75} & \multirow{2}{*}{18.4} & Above Average \\
\hline & & & & Below Average \\
\hline & \multirow{2}{*}{ Literacy rate $(\%)$} & \multirow{2}{*}{95.4} & \multirow{2}{*}{98.5} & Above Average \\
\hline & & & & Below Average \\
\hline & \multirow{2}{*}{ Higher education graduate rate $(\%)$} & \multirow{2}{*}{17.4} & \multirow{2}{*}{44.5} & Above Average \\
\hline & & & & Below Average \\
\hline \multirow{2}{*}{ Welfare state } & \multirow{2}{*}{$\begin{array}{c}\text { Car ownership } \\
(\# / 10,000 \text { people })\end{array}$} & \multirow{2}{*}{298} & \multirow{2}{*}{600} & Above Average \\
\hline & & & & Below Average \\
\hline \multicolumn{5}{|c|}{$\begin{array}{l}\text { IEED urbanization rate: The urbanization rate of OECD member countries was collected and divided by the number of members } \\
\text { } 2 \text { OECD Average Household Size: The average household size of the OECD member countries in } 2017 \text { was collected and divided by the numbe } \\
\text { members }\end{array}$} \\
\hline
\end{tabular}


Urban Resilience Assessment of Trabzon

Table 3. Evaluation of Social Resilience in Trabzon (continued)

\begin{tabular}{|c|c|c|c|c|}
\hline \multirow[t]{4}{*}{ Safety } & \multirow{3}{*}{$\begin{array}{c}\text { Number of police / military police per } 1000 \\
\text { people }\end{array}$} & \multirow{3}{*}{275} & \multirow{3}{*}{31.8} & Above Average \\
\hline & & & & \\
\hline & & & & Below Average \\
\hline & $\begin{array}{l}\text { Is the crime rate for } 1000 \text { people under the } \\
\text { OECD average? }\end{array}$ & 10.37 & & No \\
\hline \multirow{8}{*}{$\begin{array}{l}\text { Health } \\
\text { Conditions }\end{array}$} & \multirow{2}{*}{$\begin{array}{l}{ }^{4} \text { Number of medical doctor for per } 100.000 \\
\text { people }\end{array}$} & \multirow{2}{*}{224} & \multirow{2}{*}{322} & Above Average \\
\hline & & & & Below Average \\
\hline & \multirow{2}{*}{${ }^{5}$ Number of beds per 1000 persons } & \multirow{2}{*}{7.4} & \multirow{2}{*}{5.2} & Above Average \\
\hline & & & & Below Average \\
\hline & \multirow{2}{*}{${ }^{6}$ Average life expectancy } & \multirow{2}{*}{77.3} & \multirow{2}{*}{82.8} & Above Average \\
\hline & & & & Below Average \\
\hline & \multirow{2}{*}{ Crude suicide rate ( $\%$ per hundred thousand) } & \multirow{2}{*}{4.34} & \multirow{2}{*}{5.25} & Above Average \\
\hline & & & & Below Average \\
\hline Social Capital & \multicolumn{3}{|c|}{ Are there strong international non-governmental organizations? } & No \\
\hline \multicolumn{5}{|c|}{$\begin{array}{l}{ }^{4} \text { OECD. Number of medical doctors per } 100.000 \text { people: The number of doctors per } 1000 \text { people of OECD member countries was collected and divided } \\
\text { by the number of members for } 2017 \text {. Then, it is multiplied by } 100 \\
5 \text { OECD. Number of beds per } 100.000 \text { persons: The number of beds for } 1000 \text { people in OECD member countries was collected and divided the number } \\
\text { of members. Then, it is multiplied by } 100 \\
6 \text { OECD. Average life expectancy: Average life expectancy values of OECD member countries were collected and divided by the number of members } \\
\text { for } 2017\end{array}$} \\
\hline
\end{tabular}

Table 4. Evaluation of Physical-Ecological Resilience in Trabzon

\begin{tabular}{|c|c|c|c|}
\hline \multicolumn{4}{|c|}{ Physical-Ecological Resilience } \\
\hline Evaluation & Criteria & & \\
\hline \multirow{5}{*}{ Settlement Pattern } & $\begin{array}{l}\text { Are there any settlements that are not suitable for } \\
\text { settlement? }\end{array}$ & Yes & \\
\hline & Does the city have slum areas? & Yes & \\
\hline & Is there a flood disaster in the city? (10 years) & Yes & \\
\hline & Is there a sea fill area in the city? & Yes & \\
\hline & Are there any settlements on the sea fill areas? & Yes & \\
\hline \multirow{2}{*}{$\begin{array}{c}\text { Open and Green Areas } \\
\text { Pattern }\end{array}$} & Is the open green space system fragmented in the city? & Yes & \\
\hline & Is green space per person $\left(\mathrm{m}^{2}\right)$ less than the standard? & Yes & \\
\hline \multirow{3}{*}{ Physical Infrastructure } & Is there a water shortage? & & No \\
\hline & $\begin{array}{l}\text { Is there any housing not connected to the sewer } \\
\text { system? }\end{array}$ & & No \\
\hline & Is there a house not connected to the electricity grid? & & No \\
\hline
\end{tabular}

Table 5. Evaluation of Administrative-Politic Resilience in Trabzon

\begin{tabular}{|c|c|c|}
\hline \multicolumn{3}{|c|}{ Administrative-Politic Resilience } \\
\hline Evaluation & Criteria & \\
\hline \multirow{2}{*}{$\begin{array}{l}\text { Political Stability and } \\
\text { Participation }\end{array}$} & $\begin{array}{l}\text { Local Government preference is the same party } \\
\text { (10 years) }\end{array}$ & Yes \\
\hline & $\begin{array}{c}\text { Over the last decade, is the participation to } \\
\text { election more than } 65 \%(\%) ?\end{array}$ & Yes \\
\hline \multirow{4}{*}{$\begin{array}{l}\text { Emergency and Exception } \\
\text { Plans }\end{array}$} & Is there any immigration action plan? & No \\
\hline & Is there a disaster action plan? & Yes \\
\hline & Is there a Climate Action Plan? & No \\
\hline & $\begin{array}{c}\text { Is there a local government fund to do research on } \\
\text { risks? }\end{array}$ & No \\
\hline
\end{tabular}


The last resilience analyze is about the administrative or politic resilience. They are examined under two categories as political stability and participation, and emergency plans. Political stability is discussed with the ratio of participation to general election and same party preferences of residents. They have demonstrated that Trabzon is politically stable city and participation ratio to elections is high. Existence of emergency plans such as immigration action plan, disaster action plan and climate action plan is the second category of administrative resilience. They showed that Trabzon is not ready against the shocks and disasters in terms of action plans. This situation decreases the resiliency of the city.

\section{CONCLUSION}

Resilience analyses offer a new approach for the future of the cities regarding the possible shocks the cities may face and their capacities to adapt them. Planning discipline should adopt this approach and try to find new ways to intervene cities through a resilient planning perspective. Thus, this study aims to analyze the urbanization experience of Trabzon through the resilience perspective using economic, social and administrative indicators; questioning its capability to adapt.

The resistance level is calculated as \%34.68 for Trabzon. As it can be understood from the calculation, Trabzon is in the list of non-resilient city category.

Table 6. Resilience Level of Trabzon

\begin{tabular}{lcccc}
\hline Trabzon & $\begin{array}{c}\text { Physical and } \\
\text { Ecological Resilience }\end{array}$ & $\begin{array}{c}\text { Economic } \\
\text { Resilience }\end{array}$ & Social Resilience & $\begin{array}{c}\text { Administrative and } \\
\text { Politic Resilience }\end{array}$ \\
\hline Resilience Level & $\% 10$ & $\% 46.7$ & $\% 44.5$ & $\% 33.2$ \\
\hline Total Point: \% 34.68 (within 49 Indicators) & & & \\
\hline
\end{tabular}

Physical analyses of Trabzon have shown that urbanization process in the city creates fragilities (such as sea fill areas) and generate ecological risks. They make the city unprovided for ecologically possible shocks, risks and threats. Physical resilience of Trabzon is the worst category of resilience with its 10 points. According to the analysis on economic structure, the economy of the city has the tendency to grow in the last ten years but it is still very behind of OECD averages. Thus, the capital accumulation is provided mainly through service sectors in Trabzon. However, this accumulated capital cannot be adequately transferred to productive facilities in the city; which makes it vulnerable to any crises. Actually, the migration of investors and educated people to bigger cities from Trabzon after accumulating a significant capital and education is the explicit signal of such a crisis. Social resilience analysis states that Trabzon is a stable city. It does not lose its population; but especially the educated ones are migrating from the city. The qualified manpower is likely to migrate from the city. In addition, the population is aging; which increases the dependency ratio of the elderly. All of these characteristics of the city reduce the capacity of Trabzon to resist a possible crisis and recover afterwards.

In fact, resilience analyses are made using more indicators comprising more issues within a long period. However, we confronted to the general problem of Turkey on deficiency of data and their inconsistencies. This study should be thought as a starter for the analysis on economic, social and ecological resilience putting forward the fragilities of the city and should be supported with additional analysis. 


\section{REFERENCES}

Abel N D, Cumming H M, Anderies J M, 2006. Collapse and reorganization in social-ecological systems: questions, some ideas, and policy implications. Ecology and Society, 11(1): 17.

Adger W N, 2000. Social and ecological resilience: are they related? Progress in human geography, $24,347$.

Aguirre B E, 2006. Preliminary Paper 356: On the Concept of Resilience. Disaster Research Centre, University of Delaware.

Altuntaş Ö, 2018. 2018-2019 Eğitim Öğretim Yı1ı Başları, Türkiye OECD sıralamasında Nerede? BBC News, https://www.bbc.com/turkce/haberler-turkiye-45547955 (Date of Access: 17 September 2018).

Anonim, 2013. Kooperatif İstatistikleri Bülteni. T.C. Gümrük ve Ticaret Bakanlığı, Ankara.

Baker D, Sipe N, and Gleeson B, 2006. Performance-Based Planning Perspectives from the United States, Australia, and New Zealand. Journal of Planning Education and Research, 396-409.

Baud I S A, Hordjick MA 2009. Dealing with risks in urban governance: what we can learn from resilience thinking, The 4th International Conference of the International Forum on Urbanism (IFoU) 2009 Amsterdam/Delft The New Urban Question - Urbanism beyond Neo-Liberalism

Berkes F, Folke, C, eds., 1998. Linking Social and Ecological Systems: Management Practices and Social Mechanisms for Building Resilience. Cambridge, UK: Cambridge Univ. Press.

Canada O, 2011. Literacy for Life: Further Results from the Adult Literacy and Life Skills Survey. Organisation for Economic Cooperation and Development.

Cumming G, Barnes G, Perz S, Schmink M, Sieving K, Southworth J, Van Holt T, 2005. An Exploratory Framework for the Empirical Measurement of Resilience. Ecosystems, 975-987.

Cutter S, Barnes L, Berry M, Burton C, Evans E, Tate E, Webb J, 2008. Community And Regional Resilience: Perspectıves From Hazards, Disasters, And Emergency Management. Washington.

Çobanyılmaz P, Duman Yüksel Ü, 2013. Kentlerin İklim Değişikliğinden Zarar Görebilirliğinin Belirlenmesi: Ankara Örneği. Süleyman Demirel Üniversitesi Fen Bilimleri Enstitüsü Dergisi, 39-50.

Dedekoca E, 2018. Türkiye'nin OECD rekorları. Aydınlık.com.tr, https://www.aydinlik.com.tr/turkiye-nin-oecdrekorlari-ersin-dedekoca-kose-yazilari-mart-2018 (Date of Access: 2 March 2018)

Diaz J, 2019. Analysis of the Global Resilience Assessment Frameworks for the Urban Realm. 5th International Conference on Sustainable Development, (s. 1-8). Belgrade.

Dursun D, 2015. The Effects of Restructuring in the Property Development Sector on Urban Processes: A Case Study on Erzurum and Kayseri, Unpublished PhD Thesis, Department of Urban Public Policy and Local Governments, METU, Ankara

Dursun D, Yılmaz S, Yılmaz H, Irmak A, Demir M, Yavaş M, 2015. Hava Kirliliğinde Ekolojik Koridor Senaryolar1: Erzurum Kenti, Rana Medya, Erzurum

Eraydin A, 2010. Resilience Thinking for Urban Analysis and Planning: An Exploratory Research on Istanbul, 24th AESOP Annual Conference, Finland

Eraydin A, Durmaz B, Erdem A, Yaman C, Yavuz B, 2011. The Concept of Resilience: Ankara Region Case Study, Unpublished Working Report of Regional Development Studio, DEpartment of Regional Develeopment, METU, Ankara

Folke C, Carpenter S, eds, 2000. Resilience and Sustainable Development: Building Adaptive Capacity in a World of Transformations, Stockholm, Edita Norstedts Tryckeri AB.

Hill E, Wial H, Wolman H, 2008. Exploring Regional Economic Resilience. Institute of Urban and Regional UC Berkeley, 1-17.

Hill EW, Wial H, Wolman H, 2008. Exploring Regional Economic Resilience, Working Paper 2008-04, University of California, USA

Keeley B, 2007. Human Capital: How What You Know Shapes Your Life. Organisation for Economic Cooperation and Development. 
Maguire B, Hagan P, 2007. Disasters and Communities: Understanding Social Resilience. The Australian Journal of Emergency Management, 22(2), 16-20.

Marshall N, 2010. Understanding social resilience to climate variability in primary enterprises and industries. Global Environmental Change, 36-43.

McManus S, Seville E, Brunsdon D, Vargo, J, 2007. Resilience Management - A Framework for Assessing and Improveing the Resilience of Organizations, Resilient Organisations Programme, New Zealand

Morrow B, 2008. Community Resilience: A Social Justice Perspective. Washington.

OECD. 2017. Education at a glance 2017. Paris: Organisation for Economic Cooperation and Development.

OECD. 2018. International Migration Statistics. OECDiLibrary: https://www.oecd-ilibrary.org/social-issuesmigration-health/data/oecd-international-migration-statistics_mig-data-en (Date of Access: 20 June 2018)

OECD 2010. Trends in Urbanisation and Urban Policies in OECD Countries: What Lessons for China? Organisation for Economic Cooperation and Development.

OECD 2015. Environment at a Glance. Organisation for Economic Cooperation and Development.

OECD 2015. The Metropolitan Century Understanding Urbanisation and its Consequences. Organisation for Economic Cooperation and Development.

OECD 2015. The Metropolitan Century Understanding Urbanisation and its Consequences. Organisation for Economic Cooperation and Development.

OECD 2016. OECD Regions at a Glance 2016. Organisation for Economic Cooperation and Development.

OECD 2017. Health at a Glance 2017. Organisation for Economic Cooperation and Development.

OECD 2017. International Migration Outlook 2017. Paris: Organisation for Economic Cooperation and Development.

OECD 2017. ITF Transport Outlook . Organisation for Economic Cooperation and Development.

OECD 2017. Employment Outlook 2017. Organisation for Economic Cooperation and Development.

OECD 2017. Pensions at a Glance 2017. Organisation for Economic Cooperation and Development.

OECD 2017. Health care use. OECD iLibrary: https://www.oecd-ilibrary.org/social-issues-migrationhealth/health-care-use/indicator-group/english_1a1ac034-en (Date of Access:10 November 2017)

OECD 2018. International Migration Outlook 2018. Paris: Organisation for Economic Cooperation and Development.

OECD 2018. OECD Economic Outlook, Volume 2018 Issue 1. Paris: Organisation for Economic Cooperation and Development.

OECD 2018. OECD Economic Outlook, Volume 2018 Issue 2. Paris: Organisation for Economic Cooperation and Development.

OECD 2018. OECD Labour Force Statistics . Organisation for Economic Cooperation and Development.

OECD 2018. OECD-FAO Agricultural Outlook 2018-2027. Organisation for Economic Cooperation and Development.

OECD 2018. Human Capital How what you know shapes your life. Population with tertiary education. OECD i Library: https://www.oecd-ilibrary.org/education/education-at-a-glance_19991487 (Date of Access:11 September 2018)

Resilience Alliance, 2007. Urban Resilience Research Prospectus, CSIRO, Australia - Arizona State University, USA - Stockholm University, Sweden

Sharifi A, Yamagata Y, 2016. Urban Resilience Assessment: Multiple Dimensions, Criteria, and Indicators. in Sharifi A, Yamagata, Y, Urban Resilience: A Transformative Approach, pp. 259-274. Switzerland: Springer.

Stuart Dawley A P, 2008. Towards the Resilient Region. Local Economy, pp.650-667.

Tedmem, 2018. Bir Bakışta Eğitim 2018. Tedmem: https://tedmem.org/mem-notlari/degerlendirme/bir-bakistaegitim-2018\#return-note-2766-1 (Date of Access: 17 September 2018) 
Ticaret Bakanlığı Risk Yönetimi, T. v. 2017. OECD Küresel Ekonomik Görünüm Raporları. https://risk.ticaret.gov.tr: https://risk.ticaret.gov.tr/bilgi-bankasi/diger-yayin-ve-raporlar/oecd-kureselekonomik-gorunum-raporlari (Date of Access: 23 July 2017)

Tierney K, 2009. Disaster Response: Research Findings and Their Implications for Resilience Measures. Washington: CARRI .

TÜİK, 2017. Bölgesel İstatistikler

TÜIK, 2017. Gayri Safi Katma Değer Bölgesel Sonuçlar 2004-2011

TÜIK, 2017. Hanehalkı İşgücü Anketleri

TÜIK, 2018. www.tuik.gov.tr

Walker B, Salt D, Reid W, 2006. Resilience Thinking: Sustaining Ecosystems and People in a Changing World, Island Pr. 